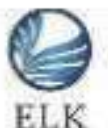

ELK

Asia Pacific Journals

www.elkjournals.com

\title{
EFFECT OF CORPORATE SOCIAL RESPOSIBILITY ON FINANCIAL PERFORMANCE OF SELECTED INDIAN COMMERCIAL BANKS- AN ANALYSIS
}

\author{
Prof. Ranjana S. Upashi \\ Assistant Professor \\ BET'S Global Business School
}

Belgaum

\begin{abstract}
Corporate entities are part of the society and they function by utilizing various resources like money, land, water and people who are the part of the society. It creates ample of scope for corporates to contribute for the social welfare and development through such social activities. And banks along with their variety of banking transactions are giving due respect to development of society through CSR activities. And these CSR initiatives are taken up by the both private and public banks with the objective to transform lives of people and society at large. The study is undertaken to know the effect of CSR on financial performance and assess the CSR spending of selected banks. Three public sector banks and private sector banks that is State Bank of India, Union Bank of India, Punjab National bank, ICICI, HDFC and Axis bank has been taken for the study based on the ranking by Futurescape. Based on the data collected from secondary sources the study is done. To represent the financial performance net profit has been used as financial indicator. The paper also focuses on CSR activities of banks selected for the study.
\end{abstract}

Key words: -CSR, Financial performance, CSR spending, Public and Private sector Banks,

JEL Classification: -M14

\section{INTRODUCTION}

\section{Corporate Social Responsibility (CSR)}

activities are corporate initiatives which aims at transforming lives of people and society at large. It is the social investment to help sustainability of society. CSR is not merely compliance; it is a commitment to support initiatives that improve the lives of underprivileged by addressing their needs.
Organizations are expected to fulfill its social obligations and they achieve this through organizing variety of social activities like donations, charity work, financial support to women to make them financially independent, rural development etc. As per Companies Act, 2013 and CSR (Policy) Rules from $1^{\text {st }}$ April 2014 doing social activities by the corporates is mandatory and this leads to making India a leading nation. 
Enforcement of the Act and its regulation is the responsibility of the Ministry of Corporate Affairs. Companies with a net worth of Rs. 500 crore (cr.) or more, or a turnover of Rs. 1000 cr. or more, or a net profit of Rs.5 cr. or more in a given financial year must spend 2 per cent of their average net profits of the last 3 years towards CSR as per the Act.

All listed companies and those who wish to get listed shall report its CSR activities in the form of Business Responsibility Report (BRR) forming a part of its annual report as per SEBI.

\section{LITERATURE REVIEW}

Nithin Venugopal and Dr. Sreela Krishnan (2018) focused on commercial banks CSR actual spending during the financial year 2014-15 and 2015-16. The researcher found that HDFC Bank stands first in CSR spending followed by State Bank of India. The spending on CSR by State Bank of India has shown an increasing trend. All the banks selected for the study except Union Bank of India as compared to previous year have shown significant increase in CSR spending. In case of Union Bank of India spending on CSR has decreased to $0.52 \%$ from $0.74 \%$. To know the level of perception of bankers and people relating to CSR activities the researcher conducted the survey and they considered promotion of education, Child welfare/Women empowerment and employment of differently abled as three issues that requires top most importance.

Muhammad Kashif Khurshid, Hammad Shaheer, Nadeem Nazir, Muhammad Waqas and Muhammad Kashif (2017) studied the impact of CSR on financial performance of 25 banks both including public and private sector banks. Results showed the CSR has an impact on return on equity. When CSR increases ROE also increases and vice versa. Return on equity and earnings per share are positively affected by CSR.

Rajnish Yadav \& Dr. F. B. Singh (2016) conducted the study to know the impact of CSR on financial performance and trends of CSR spend of selected banks. The researcher found that there is significant positive impact of CSR on financial performance. The study showed that the impact is insignificantly positive and significantly positive in public sector banks and private sector banks respectively. Trends of CSR expenditure in all selected banks in increasing.

\section{Ramandeep Mann and Karamjeet Singh} studied the relationship between CSR and financial relationship. For the study 20 banks were taken as sample. The study revealed that there is an increasing trend in CSR activities conducted by selected banks. The results showed that community and employee welfare activities positively contribute to improve financial performance. 


\section{OBJECTIVES OF THE STUDY}

1. To study about CSR activities of selected banks.

2. To assess the CSR spending by selected banks.

3. To find out the effect of CSR on financial performance on selected banks.

\section{HYPOTHESIS TESTING}

H0:-There is no significant effect of CSR on Financial Performance of the banks.

H1:-There is significant effect of CSR on Financial Performance of the banks.

\section{RESEARCH METHODOLOGY}

The study is conducted based on the data collected from secondary sources that is annual reports of the banks. For analyzing the effect of corporate social responsibility on financial performance sample of 3 public and 3 private banks that is SBI, Punjab National Bank, Union Bank of India, ICICI, HDFC and Axis Bank has been taken based the ranking by Futurescape. The study is both analytical and descriptive in nature.

\section{LIMITATIONS:}

1. Data of six years of six banks CSR spending has been taken for the study.

2. Study is based on secondary data therefore findings are also depending upon accuracy of data.

\section{DATA ANALYSIS}

To find the effect of CSR on financial performance using Net Profit as financial indicator regression model was used. CSR spending was the independent variable and Net profit was dependent variable. The data has been analyzed with the help of SPSS and MS-Excel.

\section{CSR Activities of State Bank of India}

The focus areas of CSR activities of SBI are Healthcare, Education, Sanitation, Skill Development and Livelihood Creation, Environment Protection and Culture, Sports and others. Major contribution by SBI for the year 2018 was towards Skill Development and Livelihood Creation where in bank set up 151 Rural Self Employment training institutes across the country as institution to help mitigate unemployment and underemployment problem among the youth in the country.

\section{CSR Activities of Union Bank of India}

Union Bank of India is focusing on rural sector through Village Knowledge Center which serves as information dissemination center providing instant access to farmers to latest information available in the field of agriculture, starting from crop production to marketing this aims at impacting rural livelihoods to build resourceful and progressive villages. They have donated for providing education software in government 
schools in Raibag and Thane district, treatment of cancer affected persons to Indian cancer society. They have done the donations for construction of toilet blocks at colleges, purchase of ambulance for transporting patients and for adoption of 300 girls of Udaipur by distributing books, uniform and cycle.

\section{CSR Activities of Punjab National bank}

PNB aims at "Giving Back to the Society" through its social activities. PNB focuses on spreading literacy, tree plantation drives, promoting the use renewable energy, blood donations, free medical and health checkup camps and aiding various hospitals/schools etc.

The bank has set up Hockey academy for hockey players to promote sports and nurture young talents. Banks provide all logistic support and infrastructure to the players and they are groomed as hockey players.

\section{CSR Activities of ICICI Bank}

Major focus area of CSR of ICICI is rural development and related activities. Under the banner of Skill development ICICI has ICICI Academy for Skills where they provide industry relevant and job oriented vocational training to the economically weaker sections of the society. They have set up Rural Self Employment Training Institutes (RSETIs) to provide free vocational training in locally relevant skills that empower villagers to be self-reliant. And they have trained 1,90,000 plus individuals. To empower women ICICI has launched SHG-Bank Linkage Programme exclusively for underprivileged women in rural India to start/expand their own business. On the education front ICICI foundation has partnered with the government and various NGOs to improve quality of teaching staff and curriculum and working towards improving the infrastructure in schools. They also focus on green and clean India initiatives.

\section{CSR Activities of HDFC Bank}

HDFC believes that real development of a country is possible only when communities are empowered and they achieve this through HDFC Bank Parivartan which addresses the need for socio economic empowerment through its support for rural development, promoting education, skill development etc. HDFC bank Parivartan along with a local NGO took measures to tackle the drought by constructing 31 ground water recharge structures. In order to promote education, they are helping teachers to adopt innovative and activity based learning methods through its project Disha. They are helping women to be self-reliant through training programs and financial support.

\section{CSR Activities of Axis Bank}

Axis bank has set up Axis Dil se aimed at transforming over 100 village schools in Lek 
and Kargil districts by creating physical and educational infrastructure. It provides platforms to differently abled, street children and children of sexually exploited women to educate themselves through its various educational and vocational opportunities. They have given behavioral training to over 24,600 employees.

\section{RESULTS AND DISCUSSION}

Interpretation: - For the financial year 2015-16 HDFC Bank and Axis Banks have achieved the statutory requirement of $2 \%$ of net profit for CSR activities while the remaining banks failed to achieve the legal requirements of $2 \%$. (Ref Table - 2)

Interpretation: - For the financial year 2016-17 HDFC Bank has achieved the statutory requirement of $2 \%$ of net profit for CSR activities while the remaining banks failed to achieve the legal requirements of $2 \%$. (Ref Table -3$)$

Interpretation: - For the financial year 2017-18 HDFC Bank, Axis Banks and Punjab National Bank have achieved the statutory requirement of $2 \%$ of net profit for CSR activities

The study further concluded that except ICICI Bank, all other sample banks improved their spending for CSR activities during 2017-18 as compared to the previous year 16-

\section{7. (Ref Table - 4)}

Interpretation: - State Bank of India shows highest amount of net profit for the financial year 2012-13 to 2014-15. HDFC Bank shows highest amount of net profit from the financial year 2015-16 to 2017-18, an upward trend in net profit and also CSR spending. Finally above table reveals that HDFC Bank ranks first in CSR spending followed by ICICI Bank. (Ref Table - 1)

The above tables provide $\mathrm{R}$ and $\mathrm{R}^{2}$ values of all the selected banks for the study. The $\mathrm{R}$ value represents the simple correlation and $\mathrm{R}^{2}$ value indicates how much of the total variation in the dependent variable profit can be explained by the independent variable CSR. The $\mathrm{R}$ values of SBI, UBI, ICICI and Axis Banks are 0.313, .027, 0.369 and 0.104 are indicating low degree of correlation. There is a high value of correlation in case of PNB and HDFC i.e R value is .926 and .992 respectively. In this case $\mathrm{R}^{2}$ values of SBI, UBI, ICICI and Axis Banks are 9.8\%, 0.1\%, $13.6 \%$ and $1.1 \%$ respectively which are very low. $\mathrm{R}^{2}$ values of PNB and HDFC Bank that is $85.8 \%$ and $98.3 \%$ respectively which are very high. $\mathrm{P}$ value (Sig. column) .000 is less than 0.05 indicates that result is significant and the model is good fit for the data.

The above regression model summary reveals that overall among the public and private banks PNB and HDFC bank's results are 


\section{ELK ASIA PACIFIC JOURNAL OF SOCIAL SCIENCE}

ISSN 2394-9392 (Online); DOI: 10.16962/EAPJSS/issn. 2394-9392/2015; Volume 5 Issue 1 (2018)

significant and there is significant impact of CSR on Net Profit. (Ref Table - 5)

$\mathrm{R}$ values is indicating high degree of correlation. The $\mathrm{R}^{2}$ value is $38.8 \%$ which is very low. The $\mathrm{p}$ value is 0.186 which is more than 0.05. Hence, null hypothesis is not rejected based on the insignificant result.

\section{(Ref Table -6)}

\section{CONCLUSION}

All the banks have formulated the CSR policy and CSR committee which formulates and recommends the CSR policy to the board, and they list out and recommend CSR activities and their expenditure.as per the Act. And even all the banks are disclosing their CSR related details in director's reports like CSR initiatives, expenditure etc. Statutory requirement of spending $2 \%$ of net profit for CSR activities has been achieved by HDFC Bank and Axis Bank for the financial year 2015-16 while the remaining banks failed. HDFC Bank, Axis Bank and Punjab National Bank have achieved the statutory requirement of spending $2 \%$ of net profit for CSR activities for the financial year 2017-18. Except ICICI Bank all the other banks namely State Bank of India, Punjab National Bank, Union Bank of India, HDFC Bank and Axis bank taken for the study have improved their spending for CSR activities during 2017-18 as compared to the previous year. Overall among the public and private banks PNB and HDFC Banks results are significant and there is significant impact of CSR on Net Profit. Since the investment in CSR is inconsistent impact of CSR on overall banks financial performance in insignificant. Results of these studies have been inconclusive as the sufficient CSR spending data of is unavailable and hence unable to write any firm statement on the relationship between CSR and Net Profit. Major focus area of CSR spending by banks are skill development, donations and charity, financial literacy and rural development etc. Hence, as the financial institutions, banks are playing very important role in creating suitable conditions for sustainable livelihood.

\section{REFERENCES}

1. Nithin Venugopal and Dr. Sreela Krishnan, "Corporate Social Responsibility: A Study on Spending Pattern in Indian Commercial Banks and Analysis of Perception and Awareness of Employees and Beneficiaries," Journal of Management Research and Analysis (JMRA) ISSN: 2394-2770, Impact Factor: 4.878, Volume 05 Issue 01, March 2018, Pages: 241-249.

2. Rajnish Yadav \& Dr. F. B. Singh, "Impact of Corporate Social Responsibility on Financial Performance of Indian Commercial Banks - An Analysis", Imperial Journal of Interdisciplinary Research 


\section{ELK ASIA PACIFIC JOURNAL OF SOCIAL SCIENCE}

ISSN 2394-9392 (Online); DOI: 10.16962/EAPJSS/issn. 2394-9392/2015; Volume 5 Issue 1 (2018)

(IJIR) ISSN: 2454-1362, Vol-2, Issue$12,2016$.

3. Muhammad Kashif Khurshid, Hammad Shaheer, Nadeem Nazir, Muhammad Waqas and Muhammad Kashif, "Impact of corporate social responsibility on financial performance: the role of intellectual capital", City University Research Journal Special Issue: AIC, Malaysia PP 247-263.

4. Nabasmita Bordoloi1, Dr. Kalyan Mukherjee, "A Comparative Study on the CSR Activities of Public and

Private Sector Commercial Banks",
International

Journal

of

Interdisciplinary Research in Science

Society and Culture(IJIRSSC) ISSN:

(P) 2395-4345, (O) 2455-2909, Vol:

3, Issue:1, (June Issue), 2017.

5. Annual Report of State Bank India

6. Annual Report of HDFC bank

7. Annual Report of ICICI bank

8. Annual Report of Union Bank of India

9. Annual Report of Axis bank

10. https://assets.kpmg.com/content/dam/ kpmg/in/pdf/2018/02/CSR-SurveyReport.pdf

\section{LIST OF TABLES:}

Table 1: -Net profit and CSR spending of six banks from 2013-2018.

\begin{tabular}{|c|c|c|c|c|c|c|c|c|c|c|c|c|}
\hline \multirow[b]{2}{*}{$\begin{array}{l}\text { Name of the } \\
\text { Banks }\end{array}$} & \multicolumn{2}{|c|}{$\begin{array}{l}\text { Financial Year } \\
2012-2013\end{array}$} & \multicolumn{2}{|c|}{$\begin{array}{l}\text { Financial Year } \\
\text { 2013-2014 }\end{array}$} & \multicolumn{2}{|c|}{$\begin{array}{l}\text { Financial Year } \\
\text { 2014-2015 }\end{array}$} & \multicolumn{2}{|c|}{$\begin{array}{l}\text { Financial Year } \\
2015-2016\end{array}$} & \multicolumn{2}{|c|}{$\begin{array}{l}\text { Financial Year } \\
2016-2017\end{array}$} & \multicolumn{2}{|c|}{$\begin{array}{l}\text { Financial Year } \\
2017-2018\end{array}$} \\
\hline & $\begin{array}{l}\text { Profit } \\
\text { after tax } \\
\text { (Rs. in } \\
\text { Crore) }\end{array}$ & $\begin{array}{l}\text { CSR } \\
\text { Spending } \\
\text { (Rs. in } \\
\text { Crore) }\end{array}$ & $\begin{array}{l}\text { Profit } \\
\text { after } \\
\text { tax } \\
\text { (Rs. in } \\
\text { Crore) }\end{array}$ & $\begin{array}{l}\text { CSR } \\
\text { Spending } \\
\text { (Rs. in } \\
\text { Crore) }\end{array}$ & $\begin{array}{l}\text { Profit } \\
\text { after } \\
\text { tax } \\
\text { (Rs. in } \\
\text { Crore) }\end{array}$ & $\begin{array}{l}\text { CSR } \\
\text { Spending } \\
\text { (Rs. in } \\
\text { Crore) }\end{array}$ & $\begin{array}{l}\text { Profit } \\
\text { after } \\
\text { tax } \\
\text { (Rs. in } \\
\text { Crore) }\end{array}$ & $\begin{array}{l}\text { CSR } \\
\text { Spending } \\
\text { (Rs. in } \\
\text { Crore) }\end{array}$ & $\begin{array}{l}\text { Profit } \\
\text { after tax } \\
\text { (Rs. in } \\
\text { Crore) }\end{array}$ & $\begin{array}{l}\text { CSR } \\
\text { Spending } \\
\text { (Rs. in } \\
\text { Crore) }\end{array}$ & $\begin{array}{l}\text { Profit } \\
\text { after tax } \\
\text { (Rs. in } \\
\text { Crore) }\end{array}$ & $\begin{array}{l}\text { CSR } \\
\text { Spending } \\
\text { (Rs. in } \\
\text { Crore) }\end{array}$ \\
\hline $\begin{array}{l}\text { State Bank of } \\
\text { India }\end{array}$ & 14105 & 127.00 & 10891 & 148.93 & 13102 & 115 & 9951 & 143.92 & 10484 & 109.82 & -6587 & 112.96 \\
\hline $\begin{array}{l}\text { Union Bank of } \\
\text { India }\end{array}$ & 2158 & 0.75 & 1696 & 3.77 & 1782 & 13.25 & 1352 & 6.98 & 555.21 & 7.27 & -5247.37 & 5.55 \\
\hline $\begin{array}{l}\text { Punjab National } \\
\text { Bank }\end{array}$ & 4748 & 4.00 & 3343 & 3.00 & 3062 & 3.76 & -3974 & 6.77 & 1325 & 2.72 & -12283 & 28.62 \\
\hline ICICI Bank & 8325 & 96.57 & 9810 & 192.27 & 11175 & 174.33 & 9726 & 172 & 9801 & 182 & 6777 & 170.38 \\
\hline HDFC Bank & 6726 & 39.01 & 8478 & 70.37 & 10216 & 118.55 & 12296 & 194.81 & 14550 & 305.42 & 17487 & 374 \\
\hline Axis Bank & 5179.43 & 51.8 & 6217.67 & 62.17 & 7357.82 & 135.38 & 8223.66 & 138.96 & 3679 & 135.39 & 276 & 133.77 \\
\hline
\end{tabular}


Table 2: - Average net profit and CSR spending for the financial year 2015-16

\begin{tabular}{|l|l|l|l|}
\hline Name of the Bank & $\begin{array}{l}\text { Average Net Profits of } \\
\text { Preceding 3 Years } \\
\text { Financial year 2015-16 } \\
\mathbf{( 2 0 1 2 - 1 3 , 2 0 1 3 - 1 4 , 2 0 1 4 - 1 5 )} \\
\text { (Rs. in Crore) }\end{array}$ & $\begin{array}{l}\text { Amount to be Spent } \\
\text { on CSR Activities as } \\
\text { Per Sec. 135 } \\
\text { (Rs. in Crore) }\end{array}$ & $\begin{array}{l}\text { Actual Spending } \\
\text { Financial year 2015-16 } \\
\text { (as a \% of average } \\
\text { profits of three } \\
\text { preceding years) } \\
\text { (Rs. in Crore) }\end{array}$ \\
\hline State Bank of India & 12699.33 & 253.99 & $\begin{array}{l}143.92 \\
(1.13 \%)\end{array}$ \\
\hline Union Bank of India & 1878.67 & 37.57 & $\begin{array}{l}6.98 \\
(0.37 \%)\end{array}$ \\
\hline Punjab National Bank & 3717.67 & 74.35 & $\begin{array}{l}6.77 \\
(0.18 \%)\end{array}$ \\
\hline ICICI Bank & 9770.00 & 195.40 & $\begin{array}{l}172.00 \\
(1.76 \%)\end{array}$ \\
\hline HDFC Bank & 8473.33 & 169.47 & $\begin{array}{l}194.81 \\
(2.3 \%)\end{array}$ \\
\hline Axis Bank & 6251.64 & 125.03 & $\begin{array}{l}138.96 \\
(2.22 \%)\end{array}$ \\
\hline
\end{tabular}

Table 3: - Average net profit and CSR spending for the financial year 2016-17

\begin{tabular}{|c|c|c|c|}
\hline Name of the Bank & $\begin{array}{l}\text { Average Net Profits of } \\
\text { Preceding } 3 \text { Years } \\
\text { Financial year 2016-17 } \\
(2013-14,2014-15,2015-16) \\
\text { (Rs. in Crore) }\end{array}$ & $\begin{array}{l}\text { Amount to be Spent } \\
\text { on CSR Activities as } \\
\text { Per Sec. } 135 \\
\text { (Rs. in Crore) }\end{array}$ & $\begin{array}{l}\text { Actual Spending } \\
\text { Financial year } \\
2016-17 \text { (as a \% of } \\
\text { average profits of } \\
\text { three preceding years) } \\
\text { (Rs. in Crore) }\end{array}$ \\
\hline State Bank of India & 11314.67 & 226.29 & $\begin{array}{l}109.82 \\
(0.97 \%) \\
\end{array}$ \\
\hline Union Bank of India & 1610.00 & 32.20 & $\begin{array}{l}7.27 \\
(0.45 \%)\end{array}$ \\
\hline Punjab National Bank & 810.33 & 16.21 & \begin{tabular}{|l}
2.72 \\
$(0.34 \%)$ \\
\end{tabular} \\
\hline ICICI Bank & 10237.00 & 204.74 & $\begin{array}{l}182 \\
(1.78 \%)\end{array}$ \\
\hline HDFC Bank & 10330.00 & 206.60 & \begin{tabular}{|l|}
305.42 \\
$(2.96 \%)$
\end{tabular} \\
\hline Axis Bank & 7266.38 & 145.33 & $\begin{array}{l}135.39 \\
(1.86 \%) \\
\end{array}$ \\
\hline
\end{tabular}


Table 4: - Average net profit and CSR spending for the financial year 2017-18

\begin{tabular}{|c|c|c|c|}
\hline Name of the Bank & $\begin{array}{l}\text { Average Net Profits of } \\
\text { Preceding } 3 \text { Years } \\
\text { Financial year 2017-18 } \\
(2014-15,2015-16,2016-17) \\
\text { (Rs. in Crore) }\end{array}$ & $\begin{array}{l}\text { Amount to be Spent } \\
\text { on CSR Activities as } \\
\text { Per Sec. } 135 \\
\text { (Rs. in Crore) }\end{array}$ & $\begin{array}{l}\text { Actual Spending Financial } \\
\text { year } \\
2017-18 \text { (as a \% of average } \\
\text { profits of three preceding } \\
\text { years) (Rs. in Crore) }\end{array}$ \\
\hline State Bank of India & (2. & 195.40 & $\begin{array}{l}112.96 \\
(1.16 \%)\end{array}$ \\
\hline Union Bank of India & 1229.74 & 24.59 & $\begin{array}{l}5.55 \\
(0.45 \%)\end{array}$ \\
\hline Punjab National Bank & 137.67 & 2.75 & $\begin{array}{l}28.62 \\
(20.79)\end{array}$ \\
\hline ICICI Bank & 10234.00 & 204.68 & $\begin{array}{l}170.38 \\
(1.66 \%)\end{array}$ \\
\hline HDFC Bank & 12354.00 & 247.08 & $\begin{array}{l}374 \\
(3.03 \%) \\
\end{array}$ \\
\hline Axis Bank & 6420.16 & 128.40 & $\begin{array}{l}133.77 \\
(2.08 \%)\end{array}$ \\
\hline
\end{tabular}

Table 5: -Regression Model Summary

\begin{tabular}{|c|c|c|c|c|c|c|}
\hline Name of the Bank & $\begin{array}{l}\text { Independent } \\
\text { Variable }\end{array}$ & $\begin{array}{l}\text { Dependent } \\
\text { Variable }\end{array}$ & $\mathrm{R}$ & R Square & F-Value & p-Value \\
\hline State bank of India & \multirow{6}{*}{ CSR } & \multirow{6}{*}{ Net Profit } & .313 & .098 & .435 & .546 \\
\hline $\begin{array}{l}\text { Union Bank of } \\
\text { India }\end{array}$ & & & .027 & .001 & .003 & .959 \\
\hline $\begin{array}{ll}\text { Punjab National } \\
\text { Bank }\end{array}$ & & & .926 & .858 & 24.168 & $.008^{*}$ \\
\hline ICICI Bank & & & .369 & .136 & .630 & .472 \\
\hline HDFC Bank & & & .992 & .983 & 235.890 & $.000^{8}$ \\
\hline AXIS Bank & & & .104 & .011 & .043 & .845 \\
\hline
\end{tabular}


ELK ASIA PACIFIC JOURNAL OF SOCIAL SCIENCE

ISSN 2394-9392 (Online); DOI: 10.16962/EAPJSS/issn. 2394-9392/2015; Volume 5 Issue 1 (2018)

Table 6: -Effect of CSR on overall Banking Financial Performance

\begin{tabular}{|l|l|l|l|l|l|l|}
\hline Name of the Bank & $\begin{array}{l}\text { Independent } \\
\text { Variable }\end{array}$ & $\begin{array}{l}\text { Dependent } \\
\text { Variable }\end{array}$ & $\mathrm{R}$ & R Square & F-Value & p-Value \\
\hline All the Banks & CSR & Net Profit & .623 & .388 & 2.540 & 0.186 \\
\hline
\end{tabular}

